\title{
PERIPHERAL NERVE INVOLVEMENT IN BELL'S PALSY
}

\author{
J. A. BUERI* \\ L. G. COHEN ** \\ MARCELA E. PANIZZA *** \\ OLGA P. SANZ **** \\ R. E. P. SICA *****
}

It has been emphasized in several reports that facial palsy is a common finding in the course of polyradiculoneuropathy or Guillain-Barré-Strohl syndrome $8,10,11$. In some cases it constitutes even the most conspicuous feature of that disease 3,12. Considering that Bell's palsy has a high incidence, and that there is no agreement regarding its etiology and pathophysiology we have studied in our Laboratory a group of patients with Bell's palsy as their unique clinical disease in order to evaluate the presence of subclinical involvement of other peripheral nerves.

\section{MATERIAL AND METHODS}

8 male and 12 female patients with Bell's palsy were studied. Their ages ranged from 13 to 73 years, with a mean of 33 years. All of them were exomined for the first time within three weeks after the onset of the palsy. The clinical neurological examination was normal in all patients, except for the facial palsy. In one patient it was found a hypoesthesia in the trigeminal area on the same side of the facial palsy. In 14 cases the left side was affected, and in 6 cases the right side. In all patients, other causes of neuropathy were ruled out. Every case underwent an oral glucose tolerance test, determination of blood urea nitrogen and cerebrospinal fluid (CSF) examination. In 7 patients determinations of seric cholesterol, triglicerides and tota? lipids were made.

Motor nerve conduction latencies were recorded from the affected facial nerve in 10 patients, and from both sides in the 10 remaining subjects. In every case maximal motor nerve conduction velocities as well as motor terminal latencies from thic right median and peroneal nerves were measured by employing conventional techniques. The results of the motor nerve conduction studies from the facial nerves of the 20 patients were compared to normal values from a control group of 15 adult healthy volunteers whose ages were below 60 years. The results of the maximal motor nerve conduction velocities and the motor terminal latencies of the right median and peroneal nerves were compared to normal values of a control group of 48 healthy volunteers, whose ages ranged from 18 to 53 years. Criteria for the occurrence of pclyneuropathy were the presence of diminished maximal motor nerve conduction velocities and/or prolonged motor terminal latencies in both right median and right peroneal nerves.

Department of Electroneurophysiology, Neurology Division, J. M Ramos Mejia Hospital (Buenos Aires, Argentina): * Chief of Residents in Neurology; ** Former Resident in Neurology; *** Former Chief of Residents in Neurology; **** Staff Neurologist; ***** Head of the Electroneurophysiology Department. 


\section{RESULTS}

The oral glucose tolerance test, the determination of blood urea nitrogen and the CSF laboratory examination were normal in all cases. Only one patient showed abnormal total lipids values. In all patients motor nerve conduction latencies from the clinically affected facial nerve were abnormal. In the group of 10 cases where both sides were studied, motor nerve conduction latencies in the clinically sound side differed significantly from those of control gro $\mathrm{p}$ (Table 1). Maximal motor nerve conduction velocities and motor terminal latencies of the right median and peroneal nerves showed abnormal values in 10 patients (50\%) when compared to the control group. Table 2 summarizes these data.

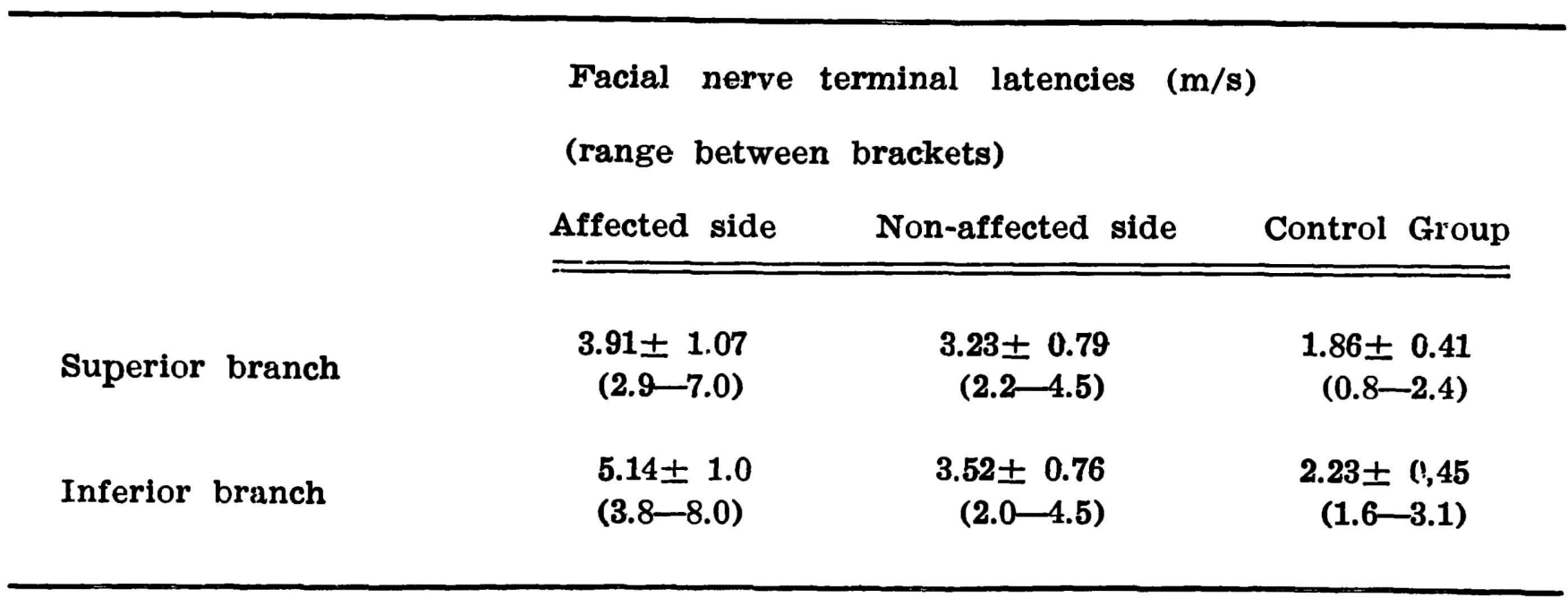

Table 1 - Means and standard deviations of facial nerve terminal latencies in the affected side in 20 patients. In 10 cases the non-affected side was studied. Statistical treatment with the " $t$ " Student test showos significant differences in both sides from. the control group. $(p<0.001)$.

\section{COMMENTS}

The etiology of Bell's palsy is still poorly understood. Different causes have been suggested, such as viral agents ${ }^{4,5,16}$ and vascular factors ${ }^{13}$, among others. Several reports in the last years have pointed out the presence of other cranial nerves involvement in the course of Bell's palsy, suggesting that it may be part of a cranial polyneuropathy 1.6. Trigeminal, vestibular, cochlear and upper cervical may be affected in addition to facial nerve, with signs of impaired function of one or more of them. The fifth cranial nerve has been found to be affected in 10 out of 16 patients ${ }^{6}$. In this series only onc patient showed diminished sensation in the trigeminal area, on the same side of the facial palsy. On the other hand, among the 10 patients where both facial nerves were studied by means of motor nerve terminal latencies, 7 showed bilateral involvement of this nerve, despite of the lack of clinical manifestations of the apparently sound side. These results are consistent with Safman's findings, who has shown that in 18 patients with unilateral Bell's palsy, 14 had subclinical neuropathy of the uninvolved side ${ }^{14}$. 


\begin{tabular}{|c|c|c|c|c|}
\hline \multirow[t]{2}{*}{ Case } & \multicolumn{2}{|c|}{ Median nerve } & \multicolumn{2}{|c|}{ Peroneal nerve } \\
\hline & $\begin{array}{l}\text { Cond. veloc. } \\
(\mathrm{m} / \mathrm{s})\end{array}$ & $\begin{array}{l}\text { Term. lat. } \\
(\mathrm{m} / \mathrm{s})\end{array}$ & $\begin{array}{l}\text { Cond. veloc. } \\
\qquad(\mathrm{m} / \mathrm{s})\end{array}$ & $\begin{array}{l}\text { Term. lat. } \\
(\mathrm{m} / \mathrm{s})\end{array}$ \\
\hline \multicolumn{5}{|c|}{ Pacients with polyneuropathy } \\
\hline 1 & 31 & 4.2 & 32 & 5.5 \\
\hline 2 & 40 & 3 & 38 & 5 \\
\hline 3 & 58 & 4.8 & 54 & 7 \\
\hline 4 & 53 & 7 & 60 & 8 \\
\hline 5 & 57 & 8 & 45 & 6 \\
\hline 6 & 55 & 5.4 & 44 & 5.2 \\
\hline 13 & 52 & 5 & 45 & 7 \\
\hline 14 & 51 & 5 & 66 & 7 \\
\hline 15 & 63 & 5.5 & 45 & 5.5 \\
\hline 16 & 50 & 5 & 50 & 6 \\
\hline \multicolumn{5}{|c|}{ Patients without polyneuropathy } \\
\hline 7 & 57 & 4.5 & 44 & $\mathbf{5}$ \\
\hline 8 & 54 & 4 & 52 & 5 \\
\hline 9 & 69 & 4.2 & 45 & 5.5 \\
\hline 10 & 55 & 3.5 & 46 & 5 \\
\hline 11 & 55 & 4.5 & 31 & 5.5 \\
\hline 12 . & 60 & 4.5 & 50 & 7 \\
\hline 17 & 52 & 4 & 52 & 5 \\
\hline 18 & 58 & 4.5 & 50 & 5 \\
\hline 19 & 52 & 4 & 50 & 4.4 \\
\hline 20 & 70 & 4 & 42 & 5 \\
\hline Ranges & $\begin{array}{l}\text { Control group } \\
58.27 \pm \text { E.24 } \\
50-71\end{array}$ & $\begin{array}{c}2.95 \pm C .56 \\
2-4.6\end{array}$ & $\begin{array}{c}49.16 \pm 5.74 \\
42-62\end{array}$ & $\begin{array}{c}4.23 \pm 0.57 \\
3-5\end{array}$ \\
\hline
\end{tabular}

Table 2 - Motor nerve conduction velocities (cond. veloc.) and terminal latencies (term. lat.) of right median and peroneal nerves in 20 patients with Bell's palsy. Diminished motor nerve conduction velocities and/or prolonged terminal latencies in both nerves were the criteria for the presence of polyneuropathy.

Chaco ${ }^{2}$, found that 5 patients from a group of 30 cases of unilateral Bell's palsy, showed pathological conduction velocities of the median and ulnar nerves. He also found that in 14 patients the opposite facial nerve exhibited an abnormal conduction latency. He suggested that there is a high frequency of involvement of the opposite facial nerve, and that other peripheral nerves may also be involved. Sandstedt et al. ${ }^{15}$ studied 112 patients with Bell's palsy, with quantitative electromyography on an asymptomatic anterior tibial muscle. They found that $31 \%$ of cases had pathological spectra in that muscle, and they also suggested that Bell's palsy could in some patients be the symptcmatic component of an acute and subclinical polyneuropathy. In our series, we have found that $50 \%$ of the cases showed either diminished motor conduction velocities or 
abnormal motor terminal latencies or both, in the median and peroneal nerves. These values are higher than those seen in the previous reports above mentioned. It is interesting to point out that none of these patients had symptoms or signs of a polyneuropathy, indicating that the involvement of the peripheral nerves was subclinical.

All the 20 patients showed normal CSF examination. We could not demonstrate abnormal findings in it. Some authors have reported increased proteins and gammaglobulins in the $\operatorname{CSF}{ }^{6,7}$, while in other reports there have been no pathological changes ${ }^{8}$.

We could not establish whether the prognosis of those cases of Bell's palsy with involvement of other peripheral nerves was different from that in cases without affection of other nerves, because of the transversal nature of our study. Nevertheless, other reports indicate that those cases have a longer recovery time ${ }^{15}$. In the present study, patients with Bell's palsy were explored searching for a subclinical involvement of peripheral nerves. The presence of pathological findings in 50\% of them supports the hypothesis that in some patients Bell's palsy is the component of a more widespread entity affecting other cranial and peripheral nerves.

\section{SUMMARY}

A group of patients with Bell's palsy were studied in order to disclose the presence of subclinical peripheral nerve involvement. 20 patients, 8 male and 12 female, with recent Bell's palsy as their unique disease were examined. In all cases other causes of polyneuropathy were ruled out. Patients were investigated with CSF examination, facial nerve latencies in the affected and in the sound sides, and maximal motor nerve conduction velocities, as well as motor terminal latencies from the right median and peroneal nerves. CSF laboratory examination was normal in all cases. Facial nerve latencies were abnormal in all patients in the affected side, and they differed significantly from those of control group in the clinically sound side. Half of the patients showed abnormal values in the maximal motor nerve conduction velocities and motor terminal latencies of the right median and peroneal nerves. These results agree with previous reports which have pointed out that other cranial nerves may be affected in Bell's palsy. However, we have found a higher frequency of peripheral nerve involvement in this entity. These findings, support the hypothesis that in some patients Bell's palsy is the component of a more widespread disease, affecting other cranial and peripheral nerves.

RESUMO

Comprometimento nervoso periférico na paralisia de Bell.

Um grupo de pacientes com paralisia de Bell foi estudadı com o objetivo de descobrir a presença de comprometimento nervoso periférico subclínico. 20 
pacientes, 8 homens e 12 mulheres com paralisia de Bell recente como única enfermidade, foram examinados. Em todos os casos outras causas de polineuropatia foram excluidas. Os pacientes foram estudados com exames de líquido cefalorraqueano; latência distal nos nervos faciais do lado afetado e do lado sadio e velocidade de condução motora máxima; latência distal dos nervos mediano e peroneiro direitos. O exame de LCR foi normal em tcdos os casos. A latência do nervo facial foi anormal em todos os pacientes no lado afetado e, no lado clinicamente sadio, diferia significativamente do grupo controle. A metade dos pacientes mostrou valores anormais na velocidade motora máxima e/ou na latência distal de ambos os nerves, como sejam: mediano e peroneiro. Esses resultados estão de acordo com publicações anteriores nas quais se afirma que outros nervos craneanos podem estar afetados na paralisia de Bell. Temos encontrado uma elevada frequência de polineuropatia nesta enfermidade. Estes achados nos levam a crer que, em alguns enfermos, a paralisia de Bell é ùn componente de uma doença mais disseminada afetando outros nervos craneanos e periféricos.

\section{REFERENCES}

1. ADAM, K. - Cranial polyneuritis and Bell's palsy. Arch. Otolaryngol. 102:262, 1976

2. CHACO, J. - Subclinical peripheral nerve involvement in unilateral Bell's palsy. Amer. J. phys. Med. $52: 195,1973$.

3. CHAROUS, D. \& SAXE, B. - The Landry-Guillain-Barré syndrome. Report of an unusual case, with a comment on Bell's palsy. N. Engl. J. Med. 267:1334, 1962.

4. DJUPESLAND, G.; BERDAL, P. \& JOHANNESSEN,. - The role of viral infection in acute peripheral facial palsy. Acta Otolaryngol. 79:221, 1975

5. DJUPESLAND, G.; BERDAL, P. \& JOHANNESSEN, T. - Viral infection as a cause of acute peripheral facial palsy. Arch. Otolaryngol. 102:403, 1976.

6. DJUPESLAND, G.; DEGRE, M.; STIEN, R. \& STKREDE, S. - Acute peripheral facial palsy. Arch. Otolaryngol. 103:641, 1977.

7. ENGELHARDT, P. - Liquorbefunde bei ein-, doppel- und vichselseitigen Fazialisparesen. Med. Klin. 71:706, 1976.

8. FIGINI, H. - Consideraciones clínicas sobre 110 casos de parálisis de Bell. Medicina (Buenos Aires) 40:167, 1980.

9. FORSTER, F.; BROWN, M. \& MERRITT, H.H. - Polyneuritis with facial diplegi^: clinical study. N. Engl. J. Med. 225:51, 1941.

10. FOX, M. \& O'CONNOR, R. - Infectious neuronitis: review of literature and presentation of 4 cases. Arch. int. Med. 69:58, 1942.

11. HAYMAKER, W. \& KERNOHAN, J. - Landry-Guillain-Barré syndrome: clinicopathologic report of 50 fatal cases and critique of literature. Medicine 28:59, 1949.

12. JONES, I. - Facial diplegia in Guillain-Barré's disease. Brit. med J. 2:84, 1954.

13. LEIBOWITZ, V. - Bell's palsy: two disease entities? Neurology (Minneapolis) $16: 1105,1966$.

14. SAFMAN, B. - Bilateral pathology in Bell's palsy. Arch. Otolaryngol. 93:55, 1971.

15. SANDSTEDT, P.; HYDEN, D. \& ODKVIST, L. - Bell's palsy: part of a polyneuropathy? Acta neurol. scand., 4:66, 1981.

16. SAUNDERS, W. - Viral infections and cranial nerve paralysis. Arch. Otolaryngol. 78:85, 1963.

Hospital J. M. Ramos Mejia, Division de Neurología, Sección de Electroneurofisiología - Urquiza 609, Buenos Aires - Argentina. 